\title{
The hydridotris(3-nitro-1,2,4-triazol-1-yl)borate, a new nitro-substituted electron withdrawing polydentate "scorpionate"-type ligand and related copper and silver phosphane complexes
}

Maura Pellei, ${ }^{a}$ Carlo Santini, ${ }^{a *}$ Marika Marinelli, ${ }^{a}$ Andrea Trasatti ${ }^{a}$ and H. V. Rasika Dias ${ }^{b}$

${ }^{b}$ School of Science and Technology - Chemistry Division, University of Camerino, via S. Agostino 1, 62032 Camerino (MC), Italy

${ }^{b}$ Department of Chemistry and Biochemistry, Box 19065, The University of Texas at Arlington, Arlington, Texas 76019-0065; USA

E-mail: carlo.santini@unicam.it (Carlo Santini)

\section{Abstract}

The new tripodal "scorpionate"-type ligand, the sodium hydridotris(3-nitro-1,2,4-triazol-1yl)borate $\mathrm{Na}\left[\mathrm{HB}\left(\mathrm{tz}^{\mathrm{NO} 2}\right)_{3}\right]$ (1), containing electron withdrawing nitro functional groups on the azolyl moiety, has been synthesized in high yield starting from 3-nitro-1,2,4-triazole and sodium borohydride. New copper $(\mathrm{I})$ and silver $(\mathrm{I})$ complexes, $\left[\mathrm{HB}\left(\mathrm{tz}^{\mathrm{NO} 2}\right)_{3}\right] \mathrm{M}\left(\mathrm{PR}_{3}\right)_{2}(\mathrm{M}=\mathrm{Cu}$ or $\mathrm{Ag} ; \mathrm{PR}_{3}=\mathrm{P}\left(\mathrm{C}_{6} \mathrm{H}_{5}\right)_{3}$, or $\left.\mathrm{P}\left(p-\mathrm{C}_{6} \mathrm{H}_{4} \mathrm{CH}_{3}\right)_{3}\right)$ have been synthesized from the reaction of $\mathrm{CuCl}$ or $\mathrm{AgNO}_{3}$ with $\mathrm{Na}\left[\mathrm{HB}\left(\mathrm{tz}^{\mathrm{NO} 2}\right)_{3}\right]$ and triphenylphosphane or tri(p-tolyl)phosphane, respectively. These compounds have been characterized by elemental analyses, FT-IR, ESI-MS and multinuclear NMR spectroscopy. X-ray crystal structure of $\mathrm{Na}\left[\mathrm{HB}\left(\mathrm{tz}^{\mathrm{NO} 2}\right)_{3}\right]$ (1) shows that it has polymeric network structure resulting from sodium atoms of tripodal $\mathrm{Na}\left[\mathrm{HB}\left(\mathrm{tz}^{\mathrm{NO} 2}\right)_{3}\right]$ forming inter-molecular $\mathrm{Na}-\mathrm{N}$ bonds to three nitrogen atoms of three neighboring triazolyl moieties of $\mathrm{Na}\left[\mathrm{HB}\left(\mathrm{tz}^{\mathrm{NO} 2}\right)_{3}\right]$. Each sodium center has distorted octahedral geometry with three short $\mathrm{Na}-\mathrm{N}$ (inter-molecular) and three long $\mathrm{Na}-\mathrm{N}$ bonds (to chelating $\mathrm{N}$-atoms of $\left[\mathrm{HB}\left(\mathrm{tz}^{\mathrm{NO} 2}\right)_{3}\right]^{-}$ligand). This nitro-substituted scorpionate ligand could be of interest due to its high coordinative flexibility from endo- to exo-polydentate coordination mode.

KEYWORDS. Silver(I); Copper(I); Chelate ligands; Scorpionates; X-ray; Phosphanes; Spectroscopy 


\section{Introduction}

Poly(pyrazolyl)borates and related scorpionate ligands [1] are some of the most widely used ligands in chemistry [2]. In the last 50 years the success of poly(pyrazolyl)borates has inspired the development of new scorpionate ligands that are excellent mono-anionic supporting ligands for most metals of the Periodic Table including $d$ - and f-block elements [2-6]. One reason for this success is arising out of their donor versatility by varying the substituents on the boron center, featuring boron-centered scorpionate ligands based on moieties such as thioimidazolyl [7-9], selenoimidazolyl [10], phosphane [11-15] and $\mathrm{N}$ heterocyclic carbenes [16-18], such as the ease of modifying the steric and electronic environment about the metal center by variation of the azolyl moiety or the substituents on the azolyl groups [3, 4, 19-28].

Our research activities in the field of Scorpionates are recently focused on the development and applications of electron withdrawing (EWG) ligands such as polyfluorinated or nitro-substituted poly(pyrazolyl)borates [29-35] and other azolyl analogs like poly(triazolyl)borates [36-39]. Their pronounced electron-withdrawing nature reduces the electron density of metal centers, favoring low oxidation states and thus enhancing the metal electron-accepting ability [40]. Scorpionate ligands with EWG substituents such as polyfluorinated and polyhalogenated poly(pyrazolyl)borates are significantly weaker donors compared to the non-fluorinated, electron rich tris(pyrazolyl)borate analogs, displaying greater catalytic activity in certain reactions like in the $\mathrm{C}-\mathrm{H}$ and $\mathrm{C}$-halogen bond functionalization chemistry via carbene insertion [41, 42]. Fluorinated scorpionate ligands permitted the isolation of a range of rare group 11 metal adducts [43-48], and are involved in several applications, as well in reversible chemo-resistive sensor for ethylene gas [49], as model active sites of enzymes and to develop catalysts to mediate other processes like oxidation [50-52], in the isolation of silver and copper catalysed homogeneous processes $[51,53-55]$, as a protective "Teflon coated" container for $\mathrm{Ag}(\mathrm{I})(\mathrm{CO})$ and $\mathrm{Ag}(\mathrm{I})\left(\mathrm{C}_{2} \mathrm{H}_{4}\right)$ fragments $[43,56-58]$ or to produce solids exhibiting bright blue phosphorescence [59]. In addition the silver $(\mathrm{I})$ adducts of highly fluorinated tris(pyrazolyl)borates show good antibacterial activity $[60,61]$.

Poly(triazolyl)borates $[19,62-70]$ are an attractive class of scorpionate ligands due to two important features: first, they are more electron-withdrawing than their poly(pyrazolyl)borate counterparts [71] and second, the remote exo-ring-nitrogen atoms, in the fourth position on the triazole rings, represent an additional binding site for metal ions resulting in new structures. In particular, they may bridge between metal centers and 
create a coordination polymer or may take part in hydrogen-bond interactions, assisting the formation of two-dimensional water intercalate or water-layer clathrates [72], thus leading to water soluble species $[66,73,74]$. Derivatives of poly(triazolyl)borates have also attracted some interest for their superoxide scavenging activity [70], in enzyme modeling [19], as components of ionic liquids [75] and in the synthesis of scorpionate-type bis- and tris(NHC)borate systems [18]. The cytotoxic activity of selected hydrophilic copper(I) complexes of poly(triazolyl)borates has also been evaluated against a panel of human tumor cell lines [36]. Discrete molecules with bis(1,2,4-triazolylidene)borate carbene ligands have been first reported by us [76], these systems showing a Janus-type coordination ability towards two metal centers to potentially afford homo-binuclear complexes. The triazole-based metal complexes containing the heteroscorpionate ligand bis(triazol-1-yl)acetate $\left(\left[\mathrm{HC}\left(\mathrm{CO}_{2}\right)(\mathrm{tz})_{2}\right]^{-}\right)$, have also attracted some interest as metalorganic frameworks (MOFs) [77], and the copper(I) complex with the tris(hydroxymethyl)phosphine co-ligand has been studied for its relevant in vitro antitumor activity [78, 79].

Dias and coworkers combined the weak donor properties of poly(triazolyl)borate ligands with the electron-withdrawing nature of halogens to obtain even weaker donor ligands

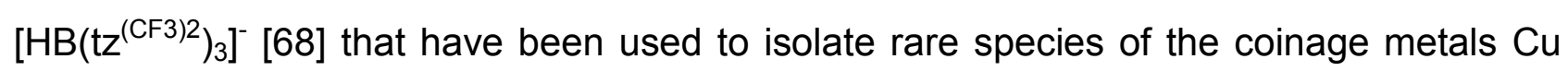
and $\mathrm{Ag}[69]$. It also allows the isolation of an interesting "tz" sandwiched sodium adduct, $\left\{\left[\mathrm{HB}\left(\mathrm{tz}^{(\mathrm{CF} 3)_{2}}\right)_{3}\right]_{2} \mathrm{Na}\right\}^{-}$. Considering the variety of effects induced by the electron withdrawing substituents, recently we decided to investigate the chemistry of a new class poly(azolyl)borate ligands, derived from 3-nitro-pyrazolyl and 3-nitro-1,2,4-triazolyl rings. In particular, we investigated the coordination chemistry of a complete series of nitrosubstituted poly(pyrazolyl)borate ligands, the mono-, bis- and tris-(3-nitro-pyrazol-1yl)borate ligands $\left[\mathrm{H}_{3} \mathrm{~B}\left(\mathrm{pz} \mathrm{NO}^{\mathrm{NO}}\right)\right]^{-},\left[\mathrm{H}_{2} \mathrm{~B}\left(\mathrm{pz}^{\mathrm{NO} 2}\right)_{2}\right]^{-}$and $\left[\mathrm{HB}\left(\mathrm{pz}^{\mathrm{NO} 2}\right)_{3}\right]^{-}$, respectively, and their copper(I) and silver(I) complexes [29, 35]. We have also reported the synthesis and characterization of the first nitro-substituted heteroscorpionate ligand, dihydridobis(3-nitro1,2,4-triazolyl)borate, $\left[\mathrm{H}_{2} \mathrm{~B}\left(\mathrm{tz}^{\mathrm{NO} 2}\right)_{2}\right]^{-}$(Figure 1a) [37] and related copper(I) [36] and silver(I) phosphane complexes [38]. Interestingly, the adduct $\left[\mathrm{H}_{2} \mathrm{~B}\left(\mathrm{tz}^{\mathrm{NO} 2}\right)_{2}\right] \mathrm{Ag}\left[\mathrm{P}(m \text {-tolyl })_{3}\right]_{2}$ has been characterized in the solid state by single crystal X-ray studies showing a mononuclear complexes, with a $\mathrm{AgP}_{2} \mathrm{~N}$ metal coordination sphere, in which the $\left[\mathrm{H}_{2} \mathrm{~B}\left(\mathrm{tz}^{\mathrm{NO} 2}\right)_{2}\right]$ ligand acts as a monodentate utilizing the coordinating capability of only one of the $N(4)$ nitrogen rings (Figure 1b) [38]. 
Figure 1. Structure of (a) bis(3-nitro-1,2,4-triazolyl)borate, $\left[\mathrm{H}_{2} \mathrm{~B}\left(\mathrm{tz}^{\mathrm{NO} 2}\right)_{2}\right]^{-}$with atom labelling scheme, and (b) related silver complex $\left[\mathrm{H}_{2} \mathrm{~B}\left(\mathrm{tz}^{\mathrm{NO} 2}\right)_{2}\right] \mathrm{Ag}\left[\mathrm{P}(m \text {-tolyl })_{3}\right]_{2}$.

Evidence of the distinctive role of the exo-ring-nitrogen atoms, $N(4)$, in tris $(1,2,4$ triazolyl)borate complexes comes from a combined X-ray crystallography and theoretical study by Janiak [72], later confirmed by ${ }^{15} \mathrm{~N}-\mathrm{NMR}$ studies [80], showing that the $\mathrm{N}(4)$ nitrogen atom in $\left[\mathrm{HB}(\mathrm{tz})_{3}\right]^{-}$has more charge on it than the $\mathrm{N}-2$ nitrogen. Coordination of the exodentate $\mathrm{N}(4)$ favors a $2 \mathrm{D}$ or a $3 \mathrm{D}$ coordination polymer formation [81, 82], nonetheless, it is the $N(2)$ that usually coordinates to the metal presumably due to formation of an ideal chelate ring size of six atoms $[66,83]$. The use of soft $\mathrm{Cu}(\mathrm{I})$ and phosphane co-ligands favors the formation of mononuclear complexes $\left[\mathrm{HB}(\mathrm{tz})_{3}\right] \mathrm{Cu}\left(\mathrm{PR}_{3}\right)$, with a $\mathrm{CuP}\left(\mathrm{N}_{3}\right)$ coordination sphere (Fig. 2a), or 1D coordination polymer structures $\left\{\left[\mathrm{HB}(\mathrm{tz})_{3}\right] \mathrm{Cu}\left(\mathrm{PR}_{3}\right)_{2}\right\}_{(\infty / \infty)}$ with a four-coordinate $\mathrm{CuP}_{2}\left(\mathrm{~N}_{2}\right)$ coordination sphere in which one of the triazole rings is uncoordinated and the other two bridge through $\mathrm{N}(4)$ to successive copper atoms (Fig. 2b) [62].

Figure 2. (a) The mononuclear complexes $\left[\mathrm{HB}(\mathrm{tz})_{3}\right] \mathrm{Cu}\left(\mathrm{PR}_{3}\right)$. (b) The $1 \mathrm{D}$ coordination polymer structures $\left\{\left[\mathrm{HB}(\mathrm{tz})_{3}\right] \mathrm{Cu}\left(\mathrm{PR}_{3}\right)_{2}\right\}_{\infty}$.

In this paper, as part of our investigations into the poly(triazolyl)borate coinage metals coordination chemistry $[36-38,62,70,84]$, we describe the synthesis and the spectroscopic and analytic characterization of the new sodium tris(3-nitro-1,2,4triazolyl)borate, $\mathrm{Na}\left[\mathrm{HB}\left(\mathrm{tz}^{\mathrm{NO} 2}\right)_{3}\right]$, ligand (Figure 3a), and related silver(I) and $\operatorname{copper}(\mathrm{I})$ 
phosphane complexes. This new ligand represents the 3-nitro-substituted analog of the widely used tris $(1,2,4$-triazolyl)borate ligands [62, 70, 84, 85]. This nitro-substituted scorpionate ligands could be of interest due to their high coordinative flexibility from endoto exo-polydentate coordination mode (Figure $3 \mathbf{b}$ ).

Figure 3. (a) Structure of the sodium tris(3-nitro-1,2,4-triazolyl)borate, $\mathrm{Na}\left[\mathrm{HB}\left(\mathrm{tz}^{\mathrm{NO} 2}\right)_{3}\right]$ showing atom labelling scheme and (b) endo- and exo-polydentate coordination mode.

\section{Experimental}

\subsection{Materials and general methods}

All reagents were purchased from Aldrich and used without further purification. All syntheses and handling were carried out under an atmosphere of dry oxygen-free dinitrogen, using standard Schlenk techniques. All solvents were dried, degassed and distilled prior to use. Elemental analyses $(\mathrm{C}, \mathrm{H}, \mathrm{N}, \mathrm{S})$ were performed in-house with a Fisons THERMO Fischer Flash 2000. IR spectra were recorded from 4000 to $400 \mathrm{~cm}^{-1}$ with a Perkin-Elmer FT-IR Spectrum100. FT-IR instrument accessorized with single reflection ATR unit (universal diamond ATR top-plate). IR annotations used: $m=$ medium, $s=$ strong, $b r=$ broad, $s h=$ shoulder, $w=$ weak. ${ }^{1} \mathrm{H},{ }^{13} \mathrm{C}$ and ${ }^{31} \mathrm{P}$ NMR spectra were recorded on an Oxford-400 Varian spectrometer $\left(400.4 \mathrm{MHz}\right.$ for ${ }^{1} \mathrm{H}, 100.1 \mathrm{MHz}$ for ${ }^{13} \mathrm{C}$, and 162.1 $\mathrm{MHz}$ for ${ }^{31} \mathrm{P}$ ). Chemical shifts, in ppm, for ${ }^{1} \mathrm{H}$ NMR spectra are relative to internal $\mathrm{Me}_{4} \mathrm{Si}$. ${ }^{13} \mathrm{C}$ NMR spectra were run with ${ }^{1} \mathrm{H}$ decoupling, and the chemical shifts are reported in ppm vs $\mathrm{Me}_{4} \mathrm{Si}$. ${ }^{31} \mathrm{P}$ NMR chemical shifts were referenced to an $85 \% \mathrm{H}_{3} \mathrm{PO}_{4}$ standard, respectively. The ${ }^{31} \mathrm{P}$ NMR spectroscopic data were accumulated with ${ }^{1} \mathrm{H}$ decoupling. NMR annotations used: $\mathrm{br}=$ broad, $\mathrm{dbr}=$ broad doublet, $\mathrm{m}=$ multiplet, $\mathrm{s}=$ singlet, $\mathrm{sbr}=$ broad singlet. Electrospray ionization mass spectra (ESI-MS) were obtained in positive- or negative-ion mode on a Series 1100 MSD detector HP spectrometer. The compounds 
were added to reagent grade methanol to give solutions of approximate concentration 0.1 $\mathrm{mM}$. These solutions were injected $(1 \mu \mathrm{l})$ into the spectrometer via a HPLC HP 1090 Series II fitted with an autosampler. The pump delivered the solutions to the mass spectrometer source at a flow rate of $300 \mu \mathrm{m} \mathrm{min}^{-1}$, and nitrogen was employed both as a drying and nebulizing gas. The fragmentation voltage was maintained at the minimum, to reduce the dissociation of the complex and ensure the maximum amount of analyte reaching the detector without significant fragmentation. Capillary voltages were typically $4000 \mathrm{~V}$ and $3500 \mathrm{~V}$ for the positive- and negative-ion mode, respectively. Confirmation of all major species in this ESI-MS study was aided by comparison of the observed and predicted isotope distribution patterns, the latter calculated using the IsoPro 3.0 computer program.

\subsection{Syntheses}

\subsubsection{Synthesis of $\mathrm{Na}\left[\mathrm{HB}\left(\mathrm{tz}^{\mathrm{NO}}\right)_{3}\right]$ (1)}

3-nitro-1,2,4-triazole $(3.108 \mathrm{~g}, 27.0 \mathrm{mmol})$ was dissolved in a mixture of anisole $(6 \mathrm{~mL})$ and kerosene $(12 \mathrm{~mL})$ and finely divided $\mathrm{NaBH}_{4}(0.297 \mathrm{~g}, 7.8 \mathrm{mmol})$ was added with an instantaneous release of hydrogen. The solution was gradually heated up to $170^{\circ} \mathrm{C}$ and kept under stirring for $12 \mathrm{~h}$. The mixture was cooled at room temperature, treated with acetone $(3 \times 20 \mathrm{~mL})$ and filtered off. The precipitate was purified by re-crystallization from methanol/diethyl ether (1:1), and dried at reduced pressure to yield derivative 1 in $69 \%$ yield. Re-crystallization of the ligand from a methanol/tetrahydrofuran solution afforded crystals suitable for the X-ray analyses. IR $\left(\mathrm{cm}^{-1}\right)$ : 3131w (CH); 2483w, 2452w (BH); 1546s $(\mathrm{C}=\mathrm{C}+\mathrm{C}=\mathrm{N})$, 1506s $\left(\mathrm{V}_{\text {asym }} \mathrm{NO}_{2}\right) ; 1417 \mathrm{~m}, 1392 \mathrm{w} ; 1347 \mathrm{~m}, 1304 \mathrm{~s}\left(\mathrm{v}_{\text {sym }} \mathrm{NO}_{2}\right) ; 1230 \mathrm{~m}$, 1178s, 1115m, 1035m, 1016s, 972w, 908m, 834s, 757m, 739s, 675sh, 654s. ${ }^{1} \mathrm{H}$ NMR $\left(\mathrm{CD}_{3} \mathrm{OD}, 293 \mathrm{~K}\right): \delta 8.58$ (s, 3H, 5-CH). ${ }^{1} \mathrm{H}$ NMR (DMSO-d, $\left.293 \mathrm{~K}\right): \delta 8.85$ (s, 3H, 5-CH). ${ }^{13} \mathrm{C}\left\{{ }^{1} \mathrm{H}\right\}$ NMR (CD $\left.\mathrm{OD}, 293 \mathrm{~K}\right): \delta 118.27(5-\mathrm{CH}), 151.58$ (3-CNO 2$)$. ESI-MS (major negativeions, $\left.\mathrm{CH}_{3} \mathrm{OH}\right), m / z(\%): 351$ (100) $\left[\mathrm{HB}\left(\mathrm{tz}^{\mathrm{NO} 2}\right)_{3}\right]^{]}$. Anal. Calcd. for $\mathrm{C}_{6} \mathrm{H}_{4} \mathrm{BN}_{12} \mathrm{NaO}_{6}$ : C, 19.27; H 1.08; N, 44.95\%. Found: C, 20.05; H, 1.20; N, 44.11\%.

\subsubsection{Synthesis of $\left[\mathrm{HB}\left(\mathrm{tz}^{\mathrm{NO} 2}\right)_{3}\right] \mathrm{Cu}\left[\mathrm{P}\left(\mathrm{C}_{6} \mathrm{H}_{5}\right)_{3}\right]_{2}$ (2)}

To an acetonitrile solution $(25 \mathrm{~mL})$ of $\mathrm{CuCl}(0.099 \mathrm{~g}, 1.0 \mathrm{mmol})$, triphenylphosphine $(0.525$ $\mathrm{g}, 2.0 \mathrm{mmol}$ ) was added at room temperature and stirred for $4 \mathrm{~h}$ to give a colourless solution. Sodium hydridotris(3- $\mathrm{NO}_{2}$-triazol-1-yl)borate, $\mathrm{Na}\left[\mathrm{HB}\left(\mathrm{tz}^{\mathrm{NO} 2}\right)_{3}\right],(0.374 \mathrm{~g}, 1.0 \mathrm{mmol})$ was added to the previous mixture. After addition, the reaction mixture was stirred for $12 \mathrm{~h}$. 
The salt was removed by filtration, the solution was concentrated under vacuum and the residue was purified by dissolving of the crude residue in hot methanol and by addition of diethyl ether to give complex 2 in 85\% yield. IR $\left(\mathrm{cm}^{-1}\right)$ : 3125w, 3050w (CH); $2497 \mathrm{w}(\mathrm{BH})$; 1546s $(\mathrm{C}=\mathrm{C}+\mathrm{C}=\mathrm{N}) ; 1498 \mathrm{~s}, 1481 \mathrm{sh}\left(\mathrm{V}_{\text {asym }} \mathrm{NO}_{2}\right) ; 1435 \mathrm{~s}, 1419 \mathrm{sh}, 1364 \mathrm{w} ; 1331 \mathrm{w}, 1300 \mathrm{~s}$ $\left(\mathrm{v}_{\text {sym }} \mathrm{NO}_{2}\right) ; 1226 \mathrm{w}, 1179 \mathrm{~m}, 1095 \mathrm{~m}, 1019 \mathrm{~m}, 833 \mathrm{~s}, 741 \mathrm{~s}, 693 \mathrm{~s}, 657 \mathrm{~m} .{ }^{1} \mathrm{H}$ NMR $\left(\mathrm{CDCl}_{3}\right.$, 293K): $\delta$ 7.20-7.45 (m, 30H, $\left.\mathrm{C}_{6} \mathrm{H}_{5}\right), 8.37$ (s, 3H, 5-CH). ${ }^{31} \mathrm{P}$ NMR $\left(\mathrm{CDCl}_{3}, 293 \mathrm{~K}\right): \delta 1.53$ (br). ESI-MS (major negative-ions, $\left.\mathrm{CH}_{3} \mathrm{OH}\right), \mathrm{m} / \mathrm{z}(\%)$ : 351 (100) $\left[\mathrm{HB}\left(\mathrm{tz}^{\mathrm{NO2}}\right)_{3}\right]^{-}$. ESI-MS

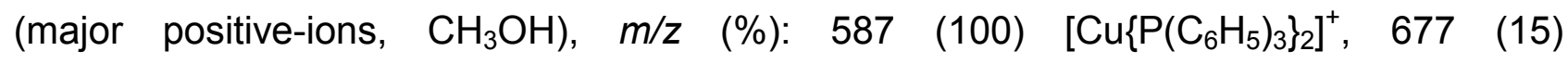
$\left[\mathrm{HB}\left(\mathrm{tz}^{\mathrm{NO} 2}\right)_{3} \mathrm{Cu}\left\{\mathrm{P}\left(\mathrm{C}_{6} \mathrm{H}_{5}\right)_{3}\right\}+\mathrm{H}\right]^{+}, \quad 850 \quad(15) \quad\left[\mathrm{Cu}\left\{\mathrm{P}\left(\mathrm{C}_{6} \mathrm{H}_{5}\right)_{3}\right\}_{3}\right]^{+}, \quad 994 \quad$ (10) $\left[\mathrm{HB}\left(\mathrm{tz}^{\mathrm{NO} 2}\right)_{3} \mathrm{Cu}\left\{\mathrm{P}\left(\mathrm{C}_{6} \mathrm{H}_{5}\right)_{3}\right\}_{2}+\mathrm{CH}_{3} \mathrm{OH}+\mathrm{Na}\right]^{+}$. Anal. Calcd. for $\mathrm{C}_{42} \mathrm{H}_{34} \mathrm{BCuN}_{12} \mathrm{O}_{6} \mathrm{P}_{2}: \mathrm{C}, 53.72$; H 3.65; N, 17.90\%. Found: C, 54.63; H, 3.90; N, 17.01\%.

\subsubsection{Synthesis of $\left[\mathrm{HB}\left(\mathrm{tz}^{\mathrm{NO} 2}\right)_{3}\right] \mathrm{Ag}\left[\mathrm{P}\left(\mathrm{C}_{6} \mathrm{H}_{5}\right)_{3}\right]_{2}$ (3)}

To a methanol solution $(25 \mathrm{~mL})$ of $\mathrm{AgNO}_{3}(0.170 \mathrm{~g}, 1.0 \mathrm{mmol})$, triphenylphosphine (0.525 $\mathrm{g}, 2.0 \mathrm{mmol}$ ) was added at room temperature and stirred for $4 \mathrm{~h}$ to give a colourless solution. Sodium hydridotris(3- $\mathrm{NO}_{2}$-triazol-1-yl)borate, $\mathrm{Na}\left[\mathrm{HB}\left(\mathrm{tz}^{\mathrm{NO} 2}\right)_{3}\right],(0.374 \mathrm{~g}, 1.0 \mathrm{mmol})$ was added to the previous mixture. After addition, the reaction mixture was stirred for $12 \mathrm{~h}$. The salt was removed by filtration, the solution was concentrated under vacuum and the residue was purified by dissolving of the crude residue in hot chloroform and by addition of diethyl ether to give complex 3 in 52\% yield. IR $\left(\mathrm{cm}^{-1}\right)$ : 3130w, 3055w (CH); 2432wbr (BH); $1551 \mathrm{~m}(\mathrm{C}=\mathrm{C}+\mathrm{C}=\mathrm{N}) ; 1479 \mathrm{~s}\left(\mathrm{~V}_{\text {asym }} \mathrm{NO}_{2}\right) ; 1435 \mathrm{~s}, 1412 \mathrm{br}, 1363 \mathrm{w} ; 1331 \mathrm{w}, 1300 \mathrm{~s}\left(\mathrm{v}_{\mathrm{sym}} \mathrm{NO}_{2}\right)$; $1179 \mathrm{~m}, 1095 \mathrm{~m}, 1019 \mathrm{~m}, 832 \mathrm{~s}, 742 \mathrm{~s}, 693 \mathrm{~s}, 659 \mathrm{~s} .{ }^{1} \mathrm{H}$ NMR $\left(\mathrm{CDCl}_{3}, 293 \mathrm{~K}\right): \delta$ 7.20-7.42 (m, $\left.30 \mathrm{H}, \mathrm{C}_{6} \mathrm{H}_{5}\right), 8.31(\mathrm{~s}, 3 \mathrm{H}, 5-\mathrm{CH}) .{ }^{31} \mathrm{P}$ NMR $\left(\mathrm{CDCl}_{3}, 293 \mathrm{~K}\right): \delta 12.15(\mathrm{br}) .{ }^{31} \mathrm{P} \mathrm{NMR}\left(\mathrm{CDCl}_{3}\right.$, 218K): $\delta 11.62\left(\mathrm{dbr},{ }^{1} \mathrm{~J}\left({ }^{31} \mathrm{P}-\mathrm{Ag}\right)=370 \mathrm{~Hz}\right)$. ESI-MS (major negative-ions, $\left.\mathrm{CH}_{3} \mathrm{OH}\right), \mathrm{m} / \mathrm{z}(\%)$ : 351 (100) $\left[\mathrm{HB}\left(\mathrm{tz}^{\mathrm{NO} 2}\right)_{3}\right]^{-}$. ESI-MS (major positive-ions, $\left.\mathrm{CH}_{3} \mathrm{OH}\right), \mathrm{m} / \mathrm{z}$ (\%): 633 (100) $\left[\mathrm{Ag}\left\{\mathrm{P}\left(\mathrm{C}_{6} \mathrm{H}_{5}\right)_{3}\right\}_{2}\right]^{+}$. Anal. Calcd. for $\mathrm{C}_{42} \mathrm{H}_{34} \mathrm{AgBN}_{12} \mathrm{O}_{6} \mathrm{P}_{2}$ : C, 51.30; $\mathrm{H} 3.48 ; \mathrm{N}, 17.09 \%$. Found: C, $52.12 ; \mathrm{H}, 3.57$; N, $16.75 \%$.

\subsubsection{Synthesis of $\left[\mathrm{HB}\left(\mathrm{tz}^{\mathrm{NO} 2}\right)_{3}\right] \mathrm{Cu}\left[\mathrm{P}\left(\mathrm{p}-\mathrm{C}_{6} \mathrm{H}_{4} \mathrm{CH}_{3}\right)_{3}\right]_{2}$ (4)}

To a methanol solution $(30 \mathrm{~mL})$ of $\mathrm{CuCl}(0.099 \mathrm{~g}, 1.0 \mathrm{mmol})$, tri $(p$-tolyl)phosphane, $\mathrm{P}(p$ $\left.\mathrm{C}_{6} \mathrm{H}_{4} \mathrm{CH}_{3}\right)_{3}(0.609 \mathrm{~g}, 2.0 \mathrm{mmol})$ was added at room temperature. The mixture was stirred for $4 \mathrm{~h}$ to give a pale yellow solution. Sodium hydridotris $\left(3-\mathrm{NO}_{2}\right.$-triazol-1-yl)borate, $\mathrm{Na}\left[\mathrm{HB}\left(\mathrm{tz}^{\mathrm{NO} 2}\right)_{3}\right],(0.449 \mathrm{~g}, 1.2 \mathrm{mmol})$ was added to the previous mixture. After addition, the reaction was stirred for $12 \mathrm{~h}$. The orange/red solution was filtered off and concentrated 
under vacuum. The resulting red solid was recovered and filtered off from $\mathrm{CHCl}_{3}$. The residue was purified by dissolving of the crude residue in hot chloroform and by addition of hexane to give complex 4 in $34 \%$ yield. IR $\left(\mathrm{cm}^{-1}\right)$ : 3020w, 2921w, 2865w (CH); $2426 \mathrm{w}$ $(\mathrm{BH}) ; 1599 \mathrm{~m} ; 1543 \mathrm{~m}(\mathrm{C}=\mathrm{C}+\mathrm{C}=\mathrm{N}) ; 1497 \mathrm{~s}\left(\mathrm{vasym}_{\mathrm{NO}}\right)$; 1446m, 1396m, 1377sh; 1299sbr $\left(\mathrm{v}_{\text {sym }} \mathrm{NO}_{2}\right) ; 1214 \mathrm{w}, 1186 \mathrm{~s}, 1163 \mathrm{~m}, 1117 \mathrm{~s}, 1096 \mathrm{~s}, 1119 \mathrm{~s}, 969 \mathrm{w}, 874 \mathrm{w}, 832 \mathrm{~s}, 804 \mathrm{~s}, 709 \mathrm{~m}$, 659s. ${ }^{1} \mathrm{H}$ NMR $\left(\mathrm{CDCl}_{3}, 293 \mathrm{~K}\right): \delta 2.32\left(\mathrm{~s}, 18 \mathrm{H}, \mathrm{CH}_{3}\right), 6.95-7.26\left(\mathrm{~m}, 24 \mathrm{H}, \mathrm{C}_{6} \mathrm{H}_{4}\right), 8.36(\mathrm{~s}, 3 \mathrm{H}$, 5-CH). ${ }^{31} \mathrm{P} \mathrm{NMR}\left(\mathrm{CDCl}_{3}, 293 \mathrm{~K}\right): \delta 1.09$ (br). ${ }^{31} \mathrm{P}$ NMR $\left(\mathrm{CDCl}_{3}, 218 \mathrm{~K}\right): \delta 1.53(\mathrm{br})$. ESI-MS (major negative-ions, $\mathrm{CH}_{3} \mathrm{OH}$ ), $\mathrm{m} / \mathrm{z}(\%): 351$ (100) $\left[\mathrm{HB}\left(\mathrm{tz}^{\mathrm{NO} 2}\right)_{3}\right]^{2}$. ESI-MS (major positiveions, $\left.\mathrm{CH}_{3} \mathrm{OH}\right), \mathrm{m} / \mathrm{z}(\%): 671(100)\left[\mathrm{Cu}\left\{\mathrm{P}\left(p-\mathrm{C}_{6} \mathrm{H}_{4} \mathrm{CH}_{3}\right)_{3}\right\}_{2}\right]^{+}, 720$ (10) $\left[\mathrm{HB}\left(\mathrm{tz}^{\mathrm{NO} 2}\right)_{3} \mathrm{Cu}\{\mathrm{P}(p-\right.$ $\left.\left.\left.\mathrm{C}_{6} \mathrm{H}_{4} \mathrm{CH}_{3}\right)_{3}\right\}+\mathrm{H}\right]^{+}, 976$ (40) $\left[\mathrm{Cu}\left\{\mathrm{P}\left(p-\mathrm{C}_{6} \mathrm{H}_{4} \mathrm{CH}_{3}\right)_{3}\right\}_{3}\right]^{+}, 1079$ (30) $\left[\mathrm{HB}\left(\mathrm{tz}^{\mathrm{NO} 2}\right)_{3} \mathrm{Cu}\{\mathrm{P}(p-\right.$ $\left.\left.\left.\mathrm{C}_{6} \mathrm{H}_{4} \mathrm{CH}_{3}\right)_{3}\right\}_{2}+\mathrm{CH}_{3} \mathrm{OH}+\mathrm{Na}\right]^{+}$. Anal. Calcd. for $\mathrm{C}_{48} \mathrm{H}_{46} \mathrm{BCuN}_{12} \mathrm{O}_{6} \mathrm{P}_{2}: \mathrm{C}, 56.34 ; \mathrm{H}$ 4.53; N, 16.43\%. Found: C, 56.00; H, 4.76; N, 15.94\%.

\subsubsection{Synthesis of $\left[\mathrm{HB}\left(t z^{\mathrm{NO} 2}\right)_{3}\right] \mathrm{Ag}\left[\mathrm{P}\left(\mathrm{p}-\mathrm{C}_{6} \mathrm{H}_{4} \mathrm{CH}_{3}\right)_{3}\right]_{2}$ (5)}

To an acetonitrile $(5 \mathrm{~mL})$ and methanol $(30 \mathrm{~mL})$ solution of $\mathrm{AgNO}_{3}(0.169 \mathrm{~g}, 1.0 \mathrm{mmol})$, tri(p-tolyl)phosphane, $\mathrm{P}\left(p-\mathrm{C}_{6} \mathrm{H}_{4} \mathrm{CH}_{3}\right)_{3}(0.609 \mathrm{~g}, 2.0 \mathrm{mmol})$ was added at room temperature and stirred for $4 \mathrm{~h}$ to give a pale yellow solution. Sodium hydridotris(3- $\mathrm{NO}_{2}$-triazol-1yl)borate, $\mathrm{Na}\left[\mathrm{HB}\left(\mathrm{tz}^{\mathrm{NO} 2}\right)_{3}\right],(0.449 \mathrm{~g}, 1.2 \mathrm{mmol})$ was added to the previous mixture. After addition, the reaction mixture was stirred for $12 \mathrm{~h}$. The solution was filtered off and concentrated under vacuum. The resulting yellow solid was recovered and filtered off from $\mathrm{CHCl}_{3}$. The residue was purified by dissolving of the crude residue in hot chloroform and by addition of hexane to give complex 5 in $57 \%$ yield. IR $\left(\mathrm{cm}^{-1}\right): 3124 \mathrm{w}, 3020 \mathrm{w}, 2956 \mathrm{sh}$, 2922w, 2863w (CH); 2430w (BH); 1598sh, 1544s ( $=\mathrm{C}+\mathrm{C}=\mathrm{N})$; 1497s ( $\left(\mathrm{v}_{\text {asym }} \mathrm{NO}_{2}\right)$; $1416 \mathrm{~m}, 1396 \mathrm{~s}, 1374 \mathrm{w} ; 1336 \mathrm{w}, 1299 \mathrm{~s}\left(\mathrm{v}_{\mathrm{sym}} \mathrm{NO}_{2}\right) ; 1223 \mathrm{~m}, 1185 \mathrm{~s}, 1097 \mathrm{~s}, 1018 \mathrm{~s}, 976 \mathrm{w}$, 878w, 832s, 804s, 732m, 708m, 659s. ${ }^{1} \mathrm{H}$ NMR $\left(\mathrm{CDCl}_{3}, 293 \mathrm{~K}\right): \delta 2.34$ (s, $\left.18 \mathrm{H}, \mathrm{CH}_{3}\right), 7.00-$ $7.26\left(\mathrm{~m}, 24 \mathrm{H}, \mathrm{C}_{6} \mathrm{H}_{4}\right), 8.31$ (s, 3H, 5-CH). ${ }^{31} \mathrm{P}$ NMR $\left(\mathrm{CDCl}_{3}, 293 \mathrm{~K}\right): \delta 11.17$ (sbr). ${ }^{31} \mathrm{P}$ NMR $\left(\mathrm{CDCl}_{3}, 218 \mathrm{~K}\right): \delta 9.93\left(\mathrm{dbr},{ }^{1} \mathrm{~J}\left({ }^{31} \mathrm{P}-\mathrm{Ag}\right)=365 \mathrm{~Hz}\right)$. ESI-MS (major negative-ions, $\mathrm{CH}_{3} \mathrm{OH}$ ), $m / z(\%): 351$ (100) $\left[\mathrm{HB}\left(\mathrm{tz}^{\mathrm{NO} 2}\right)_{3}\right]$. ESI-MS (major positive-ions, $\left.\mathrm{CH}_{3} \mathrm{OH}\right), \mathrm{m} / \mathrm{z}(\%): 715$ (100) $\left[\mathrm{Ag}\left\{\mathrm{P}\left(p-\mathrm{C}_{6} \mathrm{H}_{4} \mathrm{CH}_{3}\right)_{3}\right\}_{2}\right]^{+}, 1090(10)\left[\mathrm{HB}\left(\mathrm{tz}^{\mathrm{NO} 2}\right)_{3} \mathrm{Ag}\left\{\mathrm{P}\left(p-\mathrm{C}_{6} \mathrm{H}_{4} \mathrm{CH}_{3}\right)_{3}\right\}_{2}+\mathrm{Na}\right]^{+}$. Anal. Calcd. for $\mathrm{C}_{48} \mathrm{H}_{46} \mathrm{BAgN}_{12} \mathrm{O}_{6} \mathrm{P}_{2}: \mathrm{C}, 54.00 ; \mathrm{H} 4.34 ; \mathrm{N}, 15.74 \%$. Found: $\mathrm{C}, 54.14 ; \mathrm{H}, 4.41 ; \mathrm{N}, 15.37 \%$.

\subsection{X-ray crystallographic data}

A suitable crystal of $\mathrm{Na}\left[\mathrm{HB}\left(\mathrm{tz}^{\mathrm{NO} 2}\right)_{3}\right]$ covered with a layer of hydrocarbon/Paratone-N oil was selected and mounted on a Cryo-loop, and immediately placed in the low temperature 
nitrogen stream. The X-ray intensity data for $\mathrm{Na}\left[\mathrm{HB}\left(\mathrm{tz}^{\mathrm{NO} 2}\right)_{3}\right]$ were measured at $100(2) \mathrm{K}$ on a SMART APEX II CCD area detector system equipped with an Oxford Cryosystems 700 series cooler, a graphite monochromator, and a Mo $\mathrm{K} \alpha$ fine-focus sealed tube $(\lambda=$ $0.71073 \AA$ ). Intensity data were processed using the Bruker Apexll program suite. Absorption corrections were applied by using SADABS. All the calculations for the structure determination were carried out using the SHELXTL package (version 6.14). Initial atomic positions were located by direct methods using XS, and the structures of the compounds were refined by the least-squares method using SHELXL [86]. All the nonhydrogen atoms were refined anisotropically. X-ray structural figures were generated using Olex2 [87]. Further details are given in Table 1. The CCDC 1494614 contains the supplementary crystallographic data. These data can be obtained free of charge via http://www.ccdc.cam.ac.uk/conts/retrieving.html or from the Cambridge Crystallographic Data Centre (CCDC), 12 Union Road, Cambridge, CB2 1EZ, UK).

\section{Results and discussion}

\subsection{Synthesis and X-ray crystallography}

The sodium salt of hydridotris(3-nitro-1,2,4-triazolyl)borate, $\mathrm{Na}\left[\mathrm{HB}\left(\mathrm{tz}^{\mathrm{NO} 2}\right)_{3}\right]$ (1) has been synthesized by treating $\mathrm{NaBH}_{4}$ with 3-nitro-1,2,4-triazole in kerosene solvent (Scheme 1).

Scheme 1. Synthesis of the ligand $\mathrm{Na}\left[\mathrm{HB}\left(\mathrm{tz}^{\mathrm{NO} 2}\right)_{3}\right](1)$.

This new ligand represents the 3-nitro-substituted analogue of the previously reported tris(1,2,4-triazolyl)borate ligands [66]. Compound 1 is an air- and moisture-stable colorless solid soluble in protic solvents as water, methanol and ethanol. Recrystallization of the ligand from a methanol/tetrahydrofuran solution afforded crystals suitable for the X-ray analyses. The X-ray crystal structure of $\mathrm{Na}\left[\mathrm{HB}\left(\mathrm{tz}^{\mathrm{NO} 2}\right)_{3}\right](1)$ is illustrated in Fig. 4.

$\mathrm{Na}\left[\mathrm{HB}\left(\mathrm{tz}^{\mathrm{NO} 2}\right)_{3}\right]$ crystallizes in the trigonal $\mathrm{R} 3 \mathrm{c}$ space group and sits on a crystallographic three fold axis containing $\mathrm{H}-\mathrm{B}$ and $\mathrm{Na}$ atoms. The $\left[\mathrm{HB}\left(\mathrm{tz}^{\mathrm{NO} 2}\right)_{3}\right]^{-}$coordinates to the sodium atom in the typical tripodal fashion, with Na-N distances of 2.602(2) $\AA$. Each 
sodium atom of $\mathrm{Na}\left[\mathrm{HB}\left(\mathrm{tz}^{\mathrm{NO} 2}\right)_{3}\right]$ also form three additional bonds to the triazolyl moiety nitrogens at ring 4-positions (see Figure 3a for triazolyl moiety atom labelling scheme) of the three neighbouring $\mathrm{Na}\left[\mathrm{HB}\left(\mathrm{tz}^{\mathrm{NO} 2}\right)_{3}\right]$ molecules, creating a distorted octahedral allnitrogen coordination sphere.

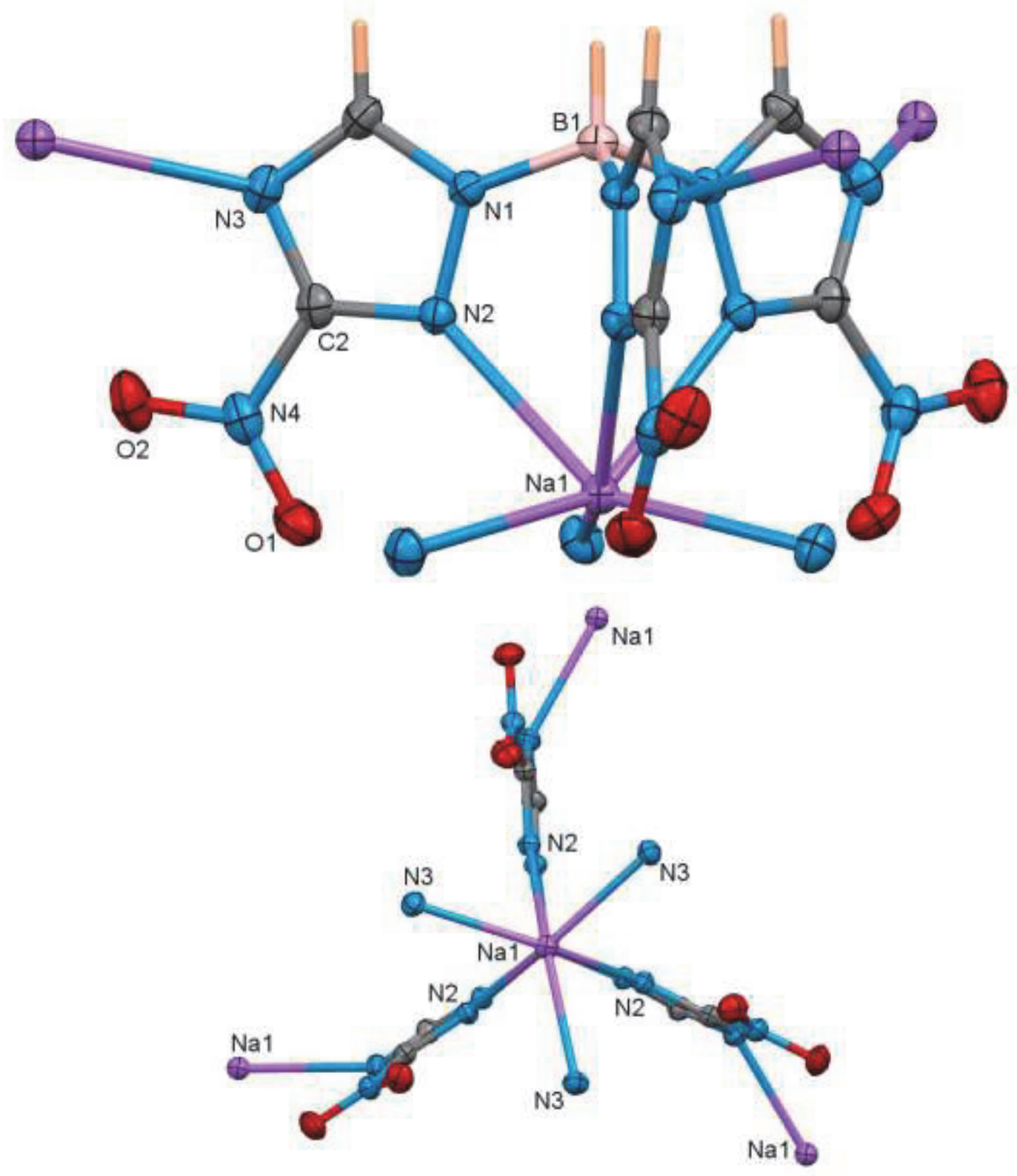

Figure 4. Molecular structure of $\mathrm{Na}\left[\mathrm{HB}\left(\mathrm{tz}^{\mathrm{NO}}\right)_{3}\right]$ (1) showing two views highlighting the coordination geometry at sodium (top) and chelating and bridging nitrogen sites of triazolyl moieties, and three fold rotation symmetry (bottom; view down Na・•B axis).

Interestingly, these inter-molecular Na-N bonds are even closer $(2.529(2) \AA)$ than the intra-molecular $\mathrm{Na}-\mathrm{N}$ distances in the tris(triazolyl)borate chelate noted above. Thus, 
all the nitrogen atoms of the triazolyl ring 2-position serve as chelating nitrogens while those at the 4-position act as bridging donors. These bridging inter-molecular $\mathrm{Na}-\mathrm{N}$ bridges lead to a 3D-network. The 3-nitro groups are co-planar with the triazolyl rings permitting the maximum delocalisation of electron density between the two moieties. There are also three, somewhat long $(3.236 \AA)$ contact between the sodium atoms and oxygen atoms of neighbouring nitro groups. There are two other structurally authenticated sodium salts of tris(triazolyl)borates known. These adducts $\left\{\mathrm{Na}(\mathrm{THF})_{6}\right\}\left\{\mathrm{HB}\left(\mathrm{tz}^{(\mathrm{CF} 3)^{2}}\right)_{3}\right]_{2}[68]$ and $\left[\mathrm{HB}\left(\mathrm{tz}^{\mathrm{t}-\mathrm{Bu}, \mathrm{Me}}\right)_{3}\right] \mathrm{Na}\left(\mathrm{H}_{2} \mathrm{O}\right)[19]$ however have very different structures with tris(triazolyl)borate ligands acting as an endo-polydentate chelate.

The 1:1:2 $\mathrm{N}$-donor:metal:triorganophosphane complexes $\mathbf{2 - 5}$ have been obtained in high yield from the reaction of one equivalent of the sodium salt $\mathrm{Na}\left[\mathrm{HB}\left(\mathrm{tz}^{\mathrm{NO} 2}\right)_{3}\right]$ with equimolar quantities of $\mathrm{CuCl}$ (Eq. (1)) or $\mathrm{AgNO}_{3}$ (Eq. (2)) and two equivalents of triphenylphosphane or tri(p-tolyl)phosphane, at room temperature in a $\mathrm{CH}_{3} \mathrm{CN}$ solution for copper complexes and in a methanol solution for silver ones. The stoichiometry of the compounds was not affected by reducing (to 1 equivalent) or increasing (>2 equivalents) the amount of the relevant phosphanes.

$\mathrm{Na}\left[\mathrm{HB}\left(\mathrm{tz}^{\mathrm{NO} 2}\right)_{3}\right]+\mathrm{CuCl}+2 \mathrm{PR}_{3} \rightarrow\left[\mathrm{HB}\left(\mathrm{tz}^{\mathrm{NO} 2}\right)_{3}\right] \mathrm{Cu}\left(\mathrm{PR}_{3}\right)_{2}$

2: $\mathrm{PR}_{3}=\mathrm{P}\left(\mathrm{C}_{6} \mathrm{H}_{5}\right)_{3}$

$4: \mathrm{PR}_{3}=\mathrm{P}\left(p-\mathrm{C}_{6} \mathrm{H}_{4} \mathrm{CH}_{3}\right)_{3}$

$\mathrm{Na}\left[\mathrm{HB}\left(\mathrm{tz}^{\mathrm{NO} 2}\right)_{3}\right]+\mathrm{AgNO}_{3}+2 \mathrm{PR}_{3} \rightarrow\left[\mathrm{HB}\left(\mathrm{tz}^{\mathrm{NO} 2}\right)_{3}\right] \mathrm{Ag}\left(\mathrm{PR}_{3}\right)_{2}$

$3: \mathrm{PR}_{3}=\mathrm{P}\left(\mathrm{C}_{6} \mathrm{H}_{5}\right)_{3}$

5: $\mathrm{PR}_{3}=\mathrm{P}\left(p-\mathrm{C}_{6} \mathrm{H}_{4} \mathrm{CH}_{3}\right)_{3}$

The colorless compounds 2-5 are quite soluble in $\mathrm{CHCl}_{3}$, methanol, acetone and DMSO and insoluble in water, diethyl ether and aliphatic or aromatic hydrocarbon solvents.

\subsection{IR, NMR spectroscopy and ESI-MS}

The authenticity of the novel ligand $\mathrm{Na}\left[\mathrm{HB}\left(\mathrm{tz}^{\mathrm{NO} 2}\right)_{3}\right](1)$ was confirmed by elemental analysis, ${ }^{1} \mathrm{H}$ and ${ }^{13} \mathrm{C}$ NMR, IR spectroscopy and electrospray ionization mass spectrometry (ESI-MS). The infrared spectrum of 1 showed weak absorption bands at 2483 and 2452 $\mathrm{cm}^{-1}$ due to the $\mathrm{B}-\mathrm{H}$ stretching vibration. The asymmetric and symmetric stretchings of the $-\mathrm{NO}_{2}$ group appear at $1506 \mathrm{~cm}^{-1}$ and $1304-1347 \mathrm{~cm}^{-1}$, in accordance with the values 
generally found for $\mathrm{C}$-nitro groups in nitro-azoles. The ${ }^{1} \mathrm{H}$ NMR chemical shift of the $5-\mathrm{CH}$ proton (in $\mathrm{CD}_{3} \mathrm{OD}$ or DMSO- $\mathrm{d}_{6}$ solution) appears at $\delta 8.58$ and $8.85 \mathrm{ppm}$, respectively; while the ${ }^{13} \mathrm{C}$ chemical shifts of $5-\mathrm{CH}$ and $3-\mathrm{CNO}_{2}$ carbons are observed at $\delta 118.27$ and $151.58 \mathrm{ppm}$, respectively. For comparison the ${ }^{13} \mathrm{C}$ chemical shifts of the $5-\mathrm{CH}$ and $3-\mathrm{CNO}_{2}$ carbons are at $151.28 \mathrm{ppm}$ and $165.37 \mathrm{ppm}$ (in $\mathrm{CD}_{3} \mathrm{OD}$ solution) in the potassium dihydridobis(3-nitro-1,2,4-triazolyl)borate [37], and at 146.20 and 163.20 ppm (in DMSO-d $d_{6}$ solution) for the starting 3-nitro-1,2,4-triazole. The ligand was also investigated by the electrospray ionization mass spectrometry. ESI-MS negative-ion spectrum of 1 in methanol is dominated by the free anionic ligand $\left[\mathrm{HB}\left(\mathrm{tz}^{\mathrm{NO} 2}\right)_{3}\right]^{-}$at $\mathrm{m} / \mathrm{z} 351(100 \%)$.

The infrared spectra of complexes 2-5 show all the bands required by the presence of the scorpionate ligand: weak absorptions in the range $3020-3130 \mathrm{~cm}^{-1}$ due to the triazole ring $\mathrm{C}-\mathrm{H}$ stretchings and medium-strong absorptions in the range $1543-1551 \mathrm{~cm}^{-1}$ related to ring "breathing" vibrations; the asymmetric and symmetric stretchings of the $\mathrm{NO}_{2}$ groups appear in the range $1479-1498 \mathrm{~cm}^{-1}$ and $1299-1336 \mathrm{~cm}^{-1}$, in accordance with the values generally found for $\mathrm{C}-\mathrm{NO}_{2}$ groups in nitro-azoles [88].

The room temperature ${ }^{1} \mathrm{H}$ NMR spectra of complexes 2-5, in $\mathrm{CDCl}_{3}$ solution, show only one set of resonances for the $H(5)$ proton, in the range 8.31-8.37 ppm. No significant variations are detected in the ${ }^{1} \mathrm{H}$ NMR profiles on lowering the temperature. The triphenylphosphane coligands in the spectra of complexes $\mathbf{2}$ and $\mathbf{4}$ show a characteristic series of resonances in the range 7.20-7.45 ppm. The tri(p-tolyl)phosphane coligands in complexes 3 and $\mathbf{5}$ show a characteristic series of resonances at 2.32 and $2.34 \mathrm{ppm}$ respectively, and in the range 6.95-7.26 ppm.

The room temperature ${ }^{31} \mathrm{P}$ NMR spectra of complexes 2-5 recorded in $\mathrm{CDCl}_{3}$ always show a single broad resonance, ascribed to some fluxional behavior of these complexes; the signals are downfield with respect to the corresponding free phosphanes. The ${ }^{31} \mathrm{P}$ NMR spectrum of $\left[\mathrm{HB}\left(\mathrm{tz}^{\mathrm{NO} 2}\right)_{3}\right] \mathrm{Cu}\left[\mathrm{P}\left(\mathrm{C}_{6} \mathrm{H}_{5}\right)_{3}\right]_{2}$ (2) recorded at $293 \mathrm{~K}$ in $\mathrm{CDCl}_{3}$ solution, displays a single signal at $1.53 \mathrm{ppm}$ suggesting the presence of a $\mathrm{CuP}_{2}$ species [35] in agreement with the elemental analyses data. In the ${ }^{31} \mathrm{P}$ NMR spectrum of $\left[\mathrm{HB}\left(\mathrm{tz}^{\mathrm{NO} 2}\right)_{3}\right] \mathrm{Ag}\left[\mathrm{P}\left(\mathrm{C}_{6} \mathrm{H}_{5}\right)_{3}\right]_{2}(3)$, only one peak at $12.15 \mathrm{ppm}$ is observed at $293 \mathrm{~K}$, while a doublet centered at $11.62 \mathrm{ppm}$ appears at $218 \mathrm{~K}$, with a coupling constant ${ }^{1} \mathrm{~J}\left(\mathrm{Ag}-{ }^{31} \mathrm{P}\right)$ of $370 \mathrm{~Hz}$, in accordance with the presence of an $\mathrm{AgP}_{2}$ species [38]. In the ${ }^{31} \mathrm{P}$ NMR spectrum of $\left[\mathrm{HB}\left(\mathrm{tz}^{\mathrm{NO} 2}\right)_{3}\right] \mathrm{Cu}\left[\mathrm{P}\left(p-\mathrm{C}_{6} \mathrm{H}_{4} \mathrm{CH}_{3}\right)_{3}\right]_{2}$ (4), a single broad signal is observed at 1.09 ppm $(293 \mathrm{~K})$ and at $1.53 \mathrm{ppm}(218 \mathrm{~K})$, suggesting the presence in solution of a $\mathrm{CuP}_{2}$ species. The ${ }^{31} \mathrm{P}$ NMR spectrum of $\left[\mathrm{HB}\left(\mathrm{tz}^{\mathrm{NO} 2}\right)_{3}\right] \mathrm{Ag}\left[\mathrm{P}\left(p-\mathrm{C}_{6} \mathrm{H}_{4} \mathrm{CH}_{3}\right)_{3}\right]_{2}(5)$ recorded at $293 \mathrm{~K}$ 
shows only one broad peak at 11.17 ppm, while lowering the temperature at $218 \mathrm{~K}$ a broad doublet appears at $9.93 \mathrm{ppm}$ with a coupling constant ${ }^{1} \mathrm{~J}\left(\mathrm{Ag}-{ }^{31} \mathrm{P}\right)$ of $365 \mathrm{~Hz}$, in accordance with the presence of an $\mathrm{AgP}_{2}$ species [38].

Electrospray ionization mass spectroscopy was used to probe the existence of aggregates of the scorpionate ligand with $\mathrm{Cu}(\mathrm{I})$ and $\mathrm{Ag}(\mathrm{I})$ phosphane coligands in solution. Both positive ion and negative-ion spectra of the complexes 2-5, dissolved in methanol, were recorded at low voltage (3.5-4.0 kV) with Fragmentor values in the range 30-75 V; under these experimental conditions the dissociation is minimal and most of the analyte is transported to the mass spectrometer as the intact molecular species [89]. In methanol solution the negative-ion spectra of compounds 2-5, were dominated by the fragment at $m / z 351(100 \%)$ due to the free scorpionate ligand, $\left[\mathrm{HB}\left(\mathrm{tz}^{\mathrm{NO} 2}\right)_{3}\right]^{-}$. The positive-ion spectra of the triphenylphosphane derivatives $\mathbf{2}$ and $\mathbf{3}$ were dominated by the fragments $\left[\mathrm{Cu}\left\{\mathrm{P}\left(\mathrm{C}_{6} \mathrm{H}_{5}\right)_{3}\right\}_{2}\right]^{+}$at $m / z 587$ and $\left[\mathrm{Ag}\left\{\mathrm{P}\left(\mathrm{C}_{6} \mathrm{H}_{5}\right)_{3}\right\}_{2}\right]^{+}$at $m / z$ 633, respectively. Analogously, the positive-ion spectra of the tri( $p$-tolyl)phosphane derivatives $\mathbf{4}$ and $\mathbf{5}$ were dominated by the fragments $\left[\mathrm{Cu}\left\{\mathrm{P}\left(p-\mathrm{C}_{6} \mathrm{H}_{4} \mathrm{CH}_{3}\right)_{3}\right\}_{2}\right]^{+}$at $\mathrm{m} / \mathrm{z} 671$ and $\left[\mathrm{Ag}\left\{\mathrm{P}\left(p-\mathrm{C}_{6} \mathrm{H}_{4} \mathrm{CH}_{3}\right)_{3}\right\}_{2}\right]^{+}$at $\mathrm{m} / \mathrm{z} \quad 715$, respectively. Lowering the Fragmentor values from $75 \mathrm{~V}$ to $30 \mathrm{~V}$ to minimize the fragmentation, we have observed in the positive-ion spectra of the triphenylphosphane derivative 2 peaks at $m / z 677,850$ and 994 due to the aggregates $\left[\mathrm{HB}\left(\mathrm{tz}^{\mathrm{NO} 2}\right)_{3} \mathrm{Cu}\left\{\mathrm{P}\left(\mathrm{C}_{6} \mathrm{H}_{5}\right)_{3}\right\}\right.$ $+\mathrm{H}]^{+}, \quad\left[\mathrm{Cu}\left\{\mathrm{P}\left(\mathrm{C}_{6} \mathrm{H}_{5}\right)_{3}\right\}_{3}\right]^{+}$and $\left[\mathrm{HB}\left(\mathrm{tz}^{\mathrm{NO} 2}\right)_{3} \mathrm{Cu}\left\{\mathrm{P}\left(\mathrm{C}_{6} \mathrm{H}_{5}\right)_{3}\right\}_{2}+\mathrm{CH}_{3} \mathrm{OH}+\mathrm{Na}\right]^{+}$, respectively. Analogous peaks were observed in the positive-ion spectra of derivative 4 at $\mathrm{m} / \mathrm{z} 720,976$, 1079 due to the species $\left[\mathrm{HB}\left(\mathrm{tz}^{\mathrm{NO} 2}\right)_{3} \mathrm{Cu}\left\{\mathrm{P}\left(p-\mathrm{C}_{6} \mathrm{H}_{4} \mathrm{CH}_{3}\right)_{3}\right\}+\mathrm{H}\right]^{+}, \quad\left[\mathrm{Cu}\left\{\mathrm{P}\left(p-\mathrm{C}_{6} \mathrm{H}_{4} \mathrm{CH}_{3}\right)_{3}\right\}_{3}\right]^{+}$, $\left[\mathrm{HB}\left(\mathrm{tz}^{\mathrm{NO} 2}\right)_{3} \mathrm{Cu}\left\{\mathrm{P}\left(p-\mathrm{C}_{6} \mathrm{H}_{4} \mathrm{CH}_{3}\right)_{3}\right\}_{2}+\mathrm{CH}_{3} \mathrm{OH}+\mathrm{Na}\right]^{+}$. In the positive-ions spectrum of $\left[\mathrm{HB}\left(\mathrm{tz}^{\mathrm{NO} 2}\right)_{3}\right] \mathrm{Ag}\left[\mathrm{P}\left(p-\mathrm{C}_{6} \mathrm{H}_{4} \mathrm{CH}_{3}\right)_{3}\right]_{2}(5)$ at $\mathrm{m} / \mathrm{z} 1090$ we have observed a peak attributable to the species $\left[\mathrm{HB}\left(\mathrm{tz}^{\mathrm{NO} 2}\right)_{3} \mathrm{Ag}\left\{\mathrm{P}\left(p-\mathrm{C}_{6} \mathrm{H}_{4} \mathrm{CH}_{3}\right)_{3}\right\}_{2}+\mathrm{Na}\right]^{+}$.

Unfortunately, despite several attempts, we could not obtain crystalline material from 2-5 suitable for X-ray crystallographic studies. Metal complexes of related poly(triazolyl)borate ligands show an enhanced capacity for the formation of unusual and unpredictable structures, often oligomeric or polymeric in nature as a consequence of the coordination ability of the remote exo-ring-nitrogen atoms in the fourth position on the triazole rings [66], higher than their poly(pyrazolyl)borates counterparts. In particular, for copper and silver complexes of $\mathrm{LM}\left(\mathrm{PR}_{3}\right)_{2}$ stoichiometry, coordination polymer structures with a four-coordinate $\mathrm{CuP}_{2}\left(\mathrm{~N}_{2}\right)$ coordination sphere in which one of the triazole rings is uncoordinated and the other two bridge through $\mathrm{N}(4)$ to successive copper atoms were observed in the species $\left\{\left[\mathrm{HB}(\mathrm{tz})_{3}\right] \mathrm{Cu}\left(\mathrm{PR}_{3}\right)_{2}\right\}_{\infty}$ [62]. A trigonal $\mathrm{AgP}_{2} \mathrm{~N}$ metal coordination 
sphere, in which the ligand acts as a monodentate utilizing the coordinating capability of only one of the $\mathrm{N}(4)$ nitrogen rings, was observed in the mononuclear, bis(triazolyl)borate complex $\left[\mathrm{H}_{2} \mathrm{~B}\left(\mathrm{tz}^{\mathrm{NO} 2}\right)_{2}\right] \mathrm{Ag}\left[\mathrm{P}(m \text {-tolyl })_{3}\right]_{2}$ [38]. In addition, an unusual exo-polydentate coordination mode in which the triazole moiety can act as a bidentate ligand utilizing the coordinating capability of only one of the $\mathrm{N}(4)$ nitrogen rings and the related nitrosubstituent was observed in the species $\left[\mathrm{H}_{2} \mathrm{~B}\left(\mathrm{tz}^{\mathrm{NO} 2}\right)_{2}\right] \mathrm{Cu}\left[\mathrm{P}(m \text {-tolyl })_{3}\right]_{2}$ (unpublished results). We also detected the coordination of the triazolyl ring nitrogens at 2 and 4 position and the related nitro-substituent to metal ions in the potassium adduct $\mathrm{K}\left[\mathrm{HB}\left(\mathrm{tz}^{\mathrm{NO} 2}\right)_{2}\right]$ [37] and in the sodium adduct $\mathrm{Na}\left[\mathrm{HB}\left(\mathrm{tz}^{\mathrm{NO} 2}\right)_{3}\right]$ reported in this manuscript. Overall, poor solubility and the IR data suggest polymeric structures for complexes 2-5 in the solid state, but it is not possible to predict the exact tris(triazolyl)borate ligand coordination mode without additional data.

\section{Concluding remarks}

We report here a new electron withdrawing tripodal "scorpionate"-type ligand that contains nitro functional groups attached to the azolyl moiety. The synthesis, characterization, and metal-ion complexation behavior of the ligand with copper $(I)$ and silver $(I)$ acceptors and phosphane coligands are discussed. $\mathrm{Na}\left[\mathrm{HB}\left(\mathrm{tz}^{\mathrm{NO} 2}\right)_{3}\right]$ crystallizes forming a polymeric network featuring chelating and bridging triazolyl moieties.

\section{Acknowledgments}

This work was supported by the University of Camerino (FAR 2014-2015) and by the US National Science Foundation (HVRD; CHE-01265807). We are grateful to CIRCMSB (Consorzio Interuniversitario di Ricerca in Chimica dei Metalli nei Sistemi Biologici).

\section{Appendix A. Supplementary data}

CCDC 1494614 contains the supplementary crystallographic data for 1 . These data can be obtained free of charge via http://www.ccdc.cam.ac.uk/conts/retrieving.html, or from the Cambridge Crystallographic Data Centre, 12 Union Road, Cambridge CB2 1EZ, UK; fax: (+44) 1223-336-033; or e-mail: deposit@ccdc.cam.ac.uk.

\section{References}

[1] S. Trofimenko, J. Am. Chem. Soc. 88 (1966) 1842-1844. 
[2] S. Trofimenko, Scorpionates: The Coordination Chemistry of Poly(pyrazolyl)borate Ligands, Imperial College Press, London, 1999.

[3] C. Santini, M. Pellei, G. Gioia Lobbia, G. Papini, Mini-Rev Org Chem 7 (2010) 84124.

[4] M. Pellei, G. Gioia Lobbia, G. Papini, C. Santini, Mini-Rev Org Chem 7 (2010) 173203.

[5] C. Pettinari, C. Santini, Compr. Coord. Chem. II, vol. 1, 2004, pp. 159-210.

[6] C. Pettinari, Scorpionates II: Chelating Borate Ligands, 2008.

[7] M.D. Spicer, J. Reglinski, Eur. J. Inorg. Chem. (2009) 1553-1574.

[8] C.G. Riordan, Coord. Chem. Rev. 254 (2010) 1815-1825.

[9] J. Reglinski, M.D. Spicer, Coord. Chem. Rev. 297-298 (2015) 181-207.

[10] M. Minoura, V.K. Landry, J.G. Melnick, K. Pang, L. Marchiò, G. Parkin, Chem. Commun. (2006) 3990-3992.

[11] A.A. Barney, A.F. Heyduk, D.G. Nocera, Chem. Commun. (1999) 2379-2380.

[12] H. Hou, A.L. Rheingold, C.P. Kubiak, Organometallics 24 (2005) 231-233.

[13] J.C. Peters, J.D. Feldman, T.D. Tilley, J. Am. Chem. Soc. 121 (1999) 9871-9872.

[14] J.M. Smith, Comments Inorg. Chem. 29 (2008) 189-233.

[15] J.C. Peters, J.C. Thomas, Inorg. Synth. 34 (2004) 8-14.

[16] U. Kernbach, M. Ramm, P. Luger, W.P. Fehlhammer, Angew. Chem., Int. Ed. 35 (1996) 310-312.

[17] R. Fränkel, J. Kniczek, W. Ponikwar, H. Nöth, K. Polborn, W.P. Fehlhammer, Inorg. Chim. Acta 312 (2001) 23-39.

[18] C. Santini, M. Marinelli, M. Pellei, Eur. J. Inorg. Chem. 2016 (2016) 2312-2331.

[19] S. Siek, N.A. Dixon, M. Kumar, J.S. Kraus, K.R. Wells, B.W. Rowe, S.P. Kelley, M. Zeller, G.P.A. Yap, E.T. Papish, Eur. J. Inorg. Chem. 2016 (2016) 2495-2507.

[20] G.M. Pawar, J.B. Sheridan, F. Jäkle, Eur. J. Inorg. Chem. 2016 (2016) 2227-2235.

[21] C. Kammerer, G. Rapenne, Eur. J. Inorg. Chem. 2016 (2016) 2214-2226.

[22] D.C. Cummins, G.P.A. Yap, K.H. Theopold, Eur. J. Inorg. Chem. 2016 (2016) 23492356.

[23] C.G. Young, Eur. J. Inorg. Chem. 2016 (2016) 2357-2376.

[24] C.J. Carrano, Eur. J. Inorg. Chem. 2016 (2016) 2377-2390.

[25] G. Steel, R. Rajasekharan-Nair, I.A. Stepek, A.R. Kennedy, J. Reglinski, M.D. Spicer, Eur. J. Inorg. Chem. 2016 (2016) 2409-2412. 
[26] M. Pellei, G. Papini, G. Gioia Lobbia, C. Santini, Current Bioactive Compounds 5 (2009) 321-352.

[27] M. Pellei, C. Santini, in: P.M. Cavrak (Ed.), Biomimetic Based Applications, InTech, 2011, pp. 385-428.

[28] C. Santini, M. Pellei (Eds.), Applications of Scorpionate Ligands in Enzyme Modeling and Biological Studies, Bentham Science, 2009.

[29] M. Pellei, S. Alidori, G. Papini, G. Gioia Lobbia, J.D. Gorden, H.V.R. Dias, C. Santini, Dalton Trans. (2007) 4845-4853.

[30] M. Pellei, G.G. Lobbia, C. Santini, R. Spagna, M. Camalli, D. Fedeli, G. Falcioni, Dalton Trans. (2004) 2822-2828.

[31] H.V.R. Dias, S. Alidori, G.G. Lobbia, G. Papini, M. Pellei, C. Santini, Inorg. Chem. 46 (2007) 9708-9714.

[32] M. Pellei, S. Alidori, G. Papini, G.G. Lobbia, J.D. Gorden, H.V.R. Dias, C. Santini, Dalton Trans. (2007) 4845-4853.

[33] H.V.R. Dias, G. Gioia Lobbia, G. Papini, M. Pellei, C. Santini, Inorg. Chem. Commun. 11 (2008) 1417-1418.

[34] H.V.R. Dias, G.G. Lobbia, G. Papini, M. Pellei, C. Santini, Eur. J. Inorg. Chem. (2009) 3935-3941.

[35] M. Pellei, G. Papini, G.G. Lobbia, S. Ricci, M. Yousufuddin, H.V. Rasika Dias, C. Santini, Dalton Trans. 39 (2010) 8937-8944.

[36] C. Marzano, M. Pellei, S. Alidori, A. Brossa, G. Gioia Lobbia, F. Tisato, C. Santini, J. Inorg. Biochem. 100 (2006) 299-304.

[37] M. Pellei, F. Benetollo, G. Gioia Lobbia, S. Alidori, C. Santini, Inorg. Chem. 44 (2005) 846-848.

[38] C. Santini, M. Pellei, S. Alidori, G. Gioia Lobbia, F. Benetollo, Inorg. Chim. Acta 360 (2007) 2121-2127.

[39] M. Giorgetti, L. Guadagnini, S.G. Fiddy, C. Santini, M. Pellei, Polyhedron 28 (2009) 3600-3606.

[40] A. Loas, S.M. Gorun, Eur. J. Inorg. Chem. 2016 (2016) 2648-2657.

[41] N.B. Jayaratna, D.B. Pardue, S. Ray, M. Yousufuddin, K.G. Thakur, T.R. Cundari, H.V.R. Dias, Dalton Trans. 42 (2013) 15399-15410.

[42] K. Rangan, M. Fianchini, S. Singh, H.V. Rasika Dias, Inorg. Chim. Acta 362 (2009) 4347-4352.

[43] H.V.R. Dias, W. Jin, J. Am. Chem. Soc. 117 (1995) 11381-11382. 
[44] H.V. Dias, S.A. Polach, S.K. Goh, E.F. Archibong, D.S. Marynick, Inorg. Chem. 39 (2000) 3894-3901.

[45] H.V.R. Dias, Z. Wang, Inorg. Chem. 39 (2000) 3724-3727.

[46] H.V.R. Dias, S.A. Polach, Inorg. Chem. 39 (2000) 4676-4677.

[47] A.E. Ayers, H.V.R. Dias, Inorg. Chem. 41 (2002) 3259-3268.

[48] S.G. Ridlen, J. Wu, N.V. Kulkarni, H.V.R. Dias, Eur. J. Inorg. Chem. 2016 (2016) 2573-2580.

[49] B. Esser, J.M. Schnorr, T.M. Swager, Angew. Chem., Int. Ed. 51 (2012) 5752-5756.

[50] P. Krishnamoorthy, R.G. Browning, S. Singh, R. Sivappa, C.J. Lovely, H.V.R. Dias, Chem. Commun. (2007) 731-733.

[51] D. Diaconu, Z. Hu, S.M. Gorun, J. Am. Chem. Soc. 124 (2002) 1564-1565.

[52] H.V.R. Dias, W. Jin, Inorg. Chem. 42 (2003) 5034-5036.

[53] H.V.R. Dias, C.J. Lovely, Chem. Rev. 108 (2008) 3223-3238.

[54] H.V.R. Dias, M. Fianchini, Comments Inorg. Chem. 28 (2007) 73-92.

[55] C. Pettinari, A. Cingolani, G. Gioia Lobbia, F. Marchetti, D. Martini, M. Pellei, R. Pettinari, C. Santini, Polyhedron 23 (2004) 451-469.

[56] H.V.R. Dias, W. Jin, Inorg. Chem. 35 (1996) 3687-3694.

[57] H.V.R. Dias, X. Wang, Dalton Trans. (2005) 2985-2987.

[58] H.V.R. Dias, Z. Wang, W. Jin, Inorg. Chem. 36 (1997) 6205-6215.

[59] M.A. Omary, M.A. Rawashdeh-Omary, H.V.K. Diyabalanage, H.V.R. Dias, Inorg. Chem. 42 (2003) 8612-8614.

[60] H.V.R. Dias, H. Batdorf Keith, M. Fianchini, V.K. Diyabalanage Himashinie, S. Carnahan, R. Mulcahy, A. Rabiee, K. Nelson, G. van Waasbergen Lorraine, J. Inorg. Biochem. 100 (2006) 158-160.

[61] L.G. van Waasbergen, I. Fajdetic, M. Fianchini, H.V.R. Dias, J. Inorg. Biochem. 101 (2007) 1180-1183.

[62] G. Gioia Lobbia, M. Pellei, C. Pettinari, C. Santini, B.W. Skelton, N. Somers, A.H. White, J. Chem. Soc., Dalton Trans. (2002) 2333-2340.

[63] E. Craven, E. Mutlu, D. Lundberg, S. Temizdemir, S. Dechert, H. Brombacher, C. Janiak, Polyhedron 21 (2002) 553-562.

[64] M. Kumar, J. DePasquale, N.J. White, M. Zeller, E.T. Papish, Organometallics 32 (2013) 2135-2144.

[65] M. Kumar, E.T. Papish, M. Zeller, A.D. Hunter, Dalton Trans. 40 (2011) 7517-7533.

[66] E.T. Papish, N.A. Dixon, M. Kumar, Struct. Bonding 160 (2014) 115-150. 
[67] N.A. Dixon, A.B. McQuarters, J.S. Kraus, J.B. Soffer, N. Lehnert, R. SchweitzerStenner, E.T. Papish, Chem. Commun. 49 (2013) 5571-5573.

[68] X. Kou, J. Wu, T.R. Cundari, H.V.R. Dias, Dalton Trans. (2009) 915-917.

[69] X. Kou, H.V.R. Dias, Dalton Trans. (2009) 7529-7536.

[70] C. Santini, M. Pellei, G.G. Lobbia, D. Fedeli, G. Falcioni, J. Inorg. Biochem. 94 (2003) 348-354.

[71] E.T. Papish, T.M. Donahue, K.R. Wells, G.P.A. Yap, Dalton Trans. (2008) 29232925.

[72] C. Janiak, J. Chem. Soc., Chem. Commun. (1994) 545-547.

[73] F.T. Edelmann, Angew. Chem., Int. Ed. 40 (2001) 1656-1660.

[74] F.E. Jernigan, III, N.A. Sieracki, M.T. Taylor, A.S. Jenkins, S.E. Engel, B.W. Rowe, F.A. Jove, G.P.A. Yap, E.T. Papish, G.M. Ferrence, Inorg. Chem. 46 (2007) 360362.

[75] Z. Zhuo, B. Twamley, J.M. Shreeve, Organometallics 26 (2007) 1782-1787.

[76] G. Papini, G. Bandoli, A. Dolmella, G. Gioia Lobbia, M. Pellei, C. Santini, Inorg. Chem. Commun. 11 (2008) 1103-1106.

[77] M. Du, Z.-H. Zhang, L.-F. Tang, X.-G. Wang, X.-J. Zhao, S.R. Batten, Chem. - Eur. J. 13 (2007) 2578-2586.

[78] C. Marzano, M. Pellei, D. Colavito, S. Alidori, G.G. Lobbia, V. Gandin, F. Tisato, C. Santini, J. Med. Chem. 49 (2006) 7317-7324.

[79] S. Alidori, G. Gioia Lobbia, G. Papini, M. Pellei, M. Porchia, F. Refosco, F. Tisato, J.S. Lewis, C. Santini, J. Biol. Inorg. Chem. 13 (2008) 307-315.

[80] C. Janiak, T.G. Scharmann, J.C. Green, R.P.G. Parkin, M.J. Kolm, E. Riedel, W. Mickler, J. Elguero, R.M. Claramunt, D. Sanz, Chem. - Eur. J. 2 (1996) 992-1000.

[81] C. Janiak, T.G. Scharmann, W. Guenther, W. Hinrichs, D. Lentz, Chem. Ber. 129 (1996) 991-995.

[82] R. Dae Won, L. Woo Ram, L. Jin Wuk, Y. Jung Hee, K. Hyoung Chan, K. Eui Kwan, H. Chang Seop, Chem. Commun. 46 (2010) 8779-8781.

[83] C. Janiak, T.G. Scharmann, W. Günther, F. Girgsdies, H. Hemling, W. Hinrichs, D. Lentz, Chem. - Eur. J. 1 (1995) 637-644.

[84] Effendy, G. Gioia Lobbia, F. Marchetti, M. Pellei, C. Pettinari, R. Pettinari, C. Santini, B.W. Skelton, A.H. White, Inorg. Chim. Acta 357 (2004) 4247-4256.

[85] G. Gioia Lobbia, M. Pellei, C. Pettinari, C. Santini, B.W. Skelton, A.H. White, Inorg. Chim. Acta 358 (2005) 1162-1170. 
[86] G.M. Sheldrick, Acta Crystallogr., Sect. A: Found. Crystallogr. 64 (2008) 112-122.

[87] O.V. Dolomanov, L.J. Bourhis, R.J. Gildea, J.A.K. Howard, H. Puschmann, Journal of Applied Crystallography 42 (2009) 339-341.

[88] K. Nakamoto, Infrared and Raman Spectra of Inorganic and Coordination Compounds, Part B. Applications in Coordination, Organometallic, and Bioinorganic Chemistry, John Wiley \& Sons, Inc., Hoboken, New Jersey, 2009.

[89] W. Henderson, J.S. McIndoe, Mass Spectrometry of Inorganic, Coordination and Organometallic Compounds, John Wiley \& Sons, Chichester, England, 2005. 

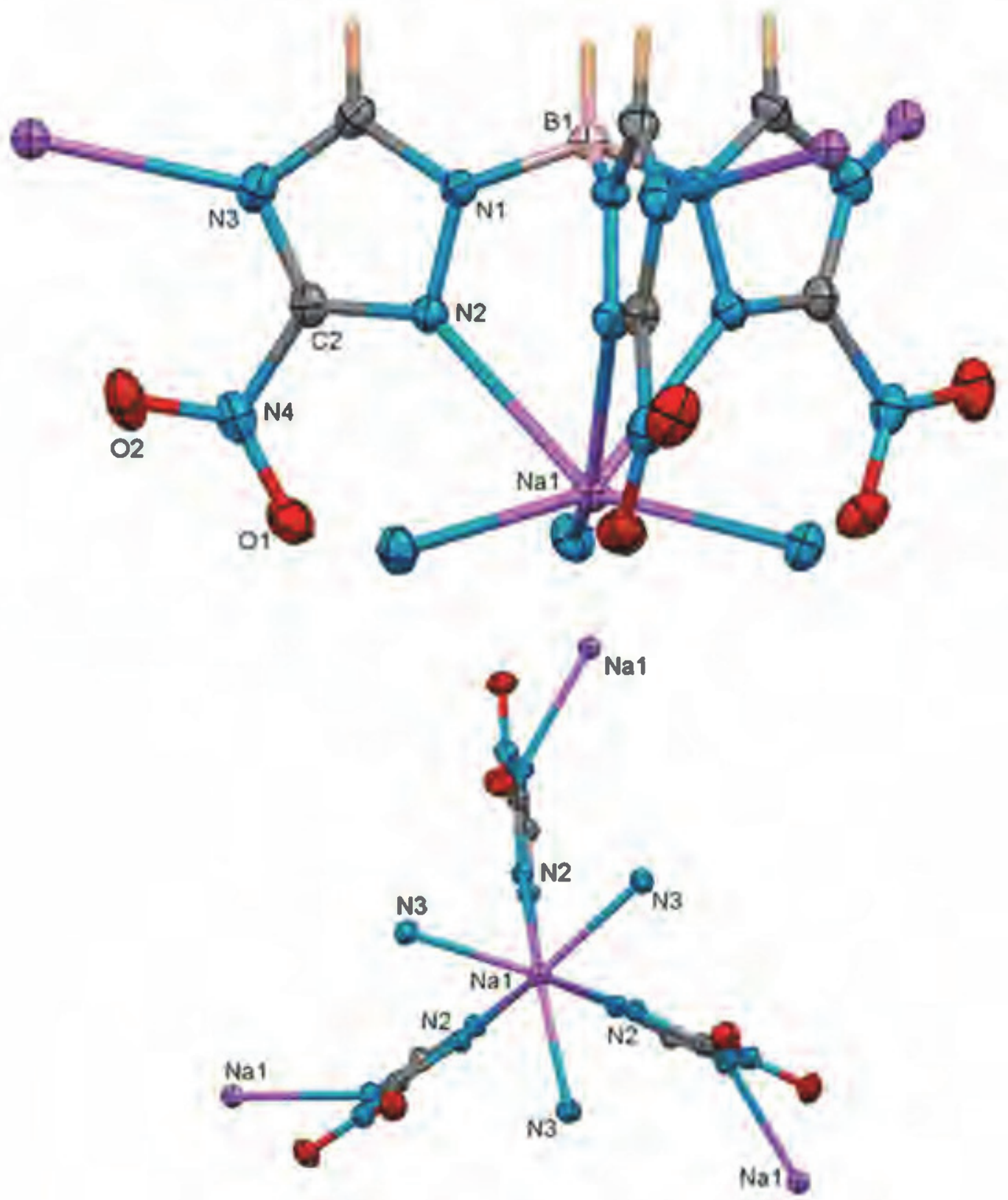


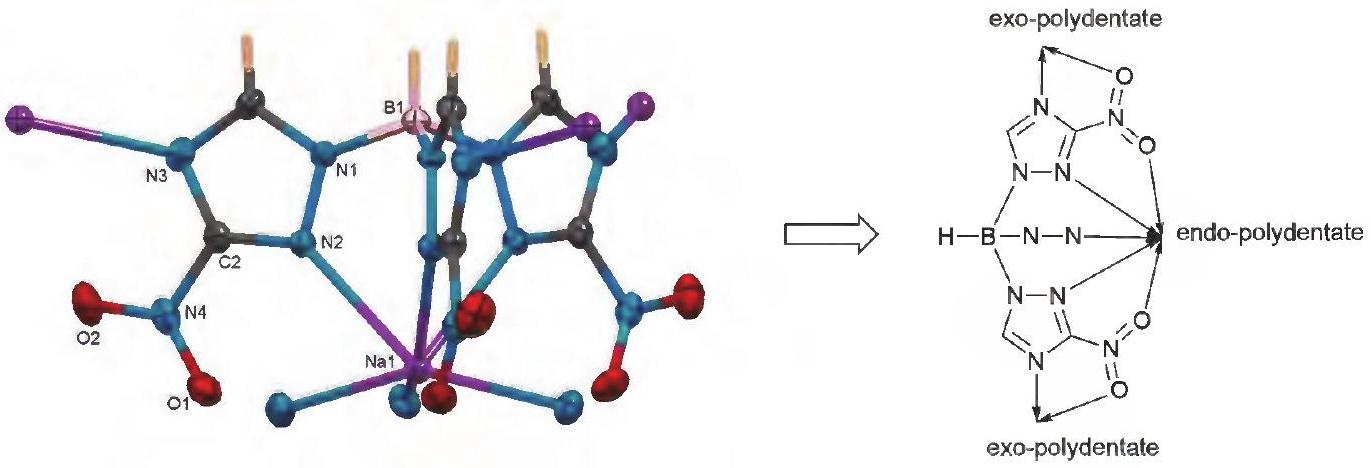


